\title{
AN ANTHROPOMETRIC MODEL FOR NUTRITION RESEARCH OF ESTONIAN FEMALE STUDENTS ${ }^{1}$
}

\author{
Jana Peterson, Helje KaARMa, SäDe Koskel \\ Centre for Physical Anthropology, University of Tartu, Tartu, Estonia
}

\begin{abstract}
The study is focused on creating an anthropometric model that would enable to associate the body build peculiarities with nutritional variables. Thirty-six body measurements and 12 skinfolds were measured on 131 17-23-year-old female students of the University of Tartu, and 12 body composition characteristics were calculated. The subjects had to submit descriptions of their 24-hour menus. Nutrient intake was determined using the Micro-Nutrica software and the food composition database; the energy (in kcal) and main nutrients (proteins, fats and carbohydrates) content in the subjects' 24-hour menus were calculated. All body measurements were compared with nutritional variables, and 29 anthropometric variables were found that showed statistically significant correlations with at least one nutrient characteristic. The amount of food consumed correlated positively with body density and negatively with weight, circumferences, skinfolds and all indicators of body fat content ( $\mathrm{r}$ reached 0.32). To associate body size, shape and composition with the amount of food consumed, a 5 SD height and weight classification was used, which consisted of three classes of concordance between height and weight (small, medium, large) and two classes of disconcordance - pyknomorphs and leptomorphs. All the 29 body measurements and nutrient were distributed systematically between the different classes. The pyknomorphous class with its greater body fat content and smaller density contrasted clearly with the class of leptomorphs. Food consumption in total as well as per $1 \mathrm{~kg}$ of body weight was smaller in pyknics
\end{abstract}

1 Originally published as "Using a height-weight classification for analysis of food energy and main nutrient contents in 24-hour menus of 17-23-year-old Estonian female students" in Anthropologischer Anzeiger 2007, 1, 51-59. 
than in leptosomes. Protein consumption did not reveal statistically significant differences. One should not overestimate the significance of BMI in nutritional studies. BMI characterises only obesity and cannot replace the characterisation of different body types. In our study, BMI of the small and the leptosomic class was almost equal, although these body types differ greatly from each other.

Key words: Body build, nutrition, anthropometry, daily energy and nutrient content, height and weight classification.

\section{INTRODUCTION}

Mutual connection between health variables, anthropometric measurements and nutrition patterns has been reported in many studies $[1,10,14,16]$. Although the relations between constitutional peculiarities and nutrition are well known, there are no universally recognized anthropometric methods for comparing the amount of food consumed by subjects with the peculiarities of their body build.

The authors of the article set themselves the aim of studying the feasibility of creating such an anthropometric model using the sample of 17-23-year-old female students of the University of Tartu.

\section{MATERIAL AND METHODS}

\section{Subjects}

The sample consisted of 131 first- and second-year female students of the University of Tartu (aged from 17 to 23 years) who were studied in 1996 and 1997.

\section{Anthropometric research}

The methodology of anthropometric study of these students relied on longterm research carried out on many populations at the Department of Obstetrics and Gynecology and the Centre for Physical Anthropology at the University of Tartu $[2,3,12]$.

Anthropometric measurements were taken personally by the first author of the article. Students were measured according to the classical method of Martin [7]. Measuring the skinfolds followed the methodology provided in Knußmann's handbook [7: 274]. 
Thirty-six anthropometric variables and 12 skinfolds were taken. For body composition analysis, body mass index, Rohrer index, body density [17], body surface area, mass and relative mass of subcutaneous adipose tissue, and relative mass of fat by Siri were calculated. In addition, total cross-sectional areas of arm and thigh and the bone-muscle and fat rate of their cross-sectional areas were calculated.

The subjects were also asked to submit descriptions of their 24-hour menus. For filling in their food-diaries, they were instructed to choose a regular working day.

\section{Statistical analysis}

Statistical analysis was performed using the SAS-program. First the mean values $(\overline{\mathrm{X}})$ and standard deviations of all anthropometric variables were calculated for age groups 17-23. However, as age-related anthropometric differences were mostly insignificant, the students were further analysed as one group.

Nutrient intake was determined using the Micro-Nutrica software and the food composition database [11]. The collected data were used to calculate the most essential energy and nutrient contents of individual 24-hour menus: food energy (kcal), proteins $(\mathrm{g})$, fats $(\mathrm{g})$ and carbohydrates $(\mathrm{g})$.

Thereafter, correlations were found between all the body measurements and food energy and main nutrient content in the menu. Table 1 lists these body measurements (29) that showed statistically significant correlations with at least one nutrient.

To further assess the body measurements that were in statistically significant correlation with nutrition from the viewpoint of the body as a whole, a 5 SD classification of height and weight was used. The application of this classification for assessment of the anthropometric aspect of the body as a whole has justified itself in our earlier studies $[5,9,12]$, as it enables systematic comparison of length, breadth and depth measurements, circumferences and body composition characteristics in many populations.

The basis for creating of the classification was the mean height, weight and their standard deviations of all young women. To create the 5 SD classification, initially $3 \times 3=9$ SD classes of height and weight were formed. From these nine classes, we took three classes of concordance between height and weight (small height - small weight, medium height - medium weight, big height - big weight). The remaining six classes were joined into two classes of disconcordant height and weight (pyknomorphs with big weight and small height, and leptomorphs with small weight and big height; see Fig. 1). 
Table 1. Correlations between anthropometric variables and consumption of energy and main nutrients in female students aged $17-23$ years $(n=131)$.

\begin{tabular}{|c|c|c|c|c|}
\hline Variable & $\begin{array}{c}\text { Energy } \\
\text { (kcal) }\end{array}$ & $\begin{array}{l}\text { Proteins } \\
(\mathrm{g})\end{array}$ & $\begin{array}{l}\text { Fats } \\
\text { (g) }\end{array}$ & $\begin{array}{c}\text { Carbohydrates } \\
\text { (g) }\end{array}$ \\
\hline Weight & $-0.21^{\circ}$ & -0.12 & -0.14 & $-0.23^{\circ}$ \\
\hline Waist circumference & -0.17 & -0.07 & -0.10 & $-0.21^{\circ}$ \\
\hline Pelvis circumference & $-0.23^{\circ}$ & -0.10 & -0.17 & $-0.25^{\circ}$ \\
\hline Hip circumference & $-0.25^{\circ}$ & -0.14 & -0.18 & $-0.25^{\circ}$ \\
\hline Waist skinfold & $-0.25^{\circ}$ & -0.16 & -0.18 & $-0.27^{\circ}$ \\
\hline Suprailiac skinfold & $-0.28^{\circ}$ & -0.15 & $-0.22^{\circ}$ & $-0.28^{\circ}$ \\
\hline Umbilical skinfold & $-0.30^{\circ}$ & -0.22 & $-0.22^{\circ}$ & $-0.30^{\circ}$ \\
\hline Subscapular skinfold & $-0.30^{\circ}$ & -0.17 & $-0.21^{\circ}$ & $-0.32^{\circ}$ \\
\hline Thigh skinfold & $-0.27^{\circ}$ & -0.15 & $-0.20^{\circ}$ & $-0.28^{\circ}$ \\
\hline BMI & $-0.26^{\circ}$ & $-0.15^{\circ}$ & -0.23 & $-0.24^{\circ}$ \\
\hline Rohrer index & $-0.23^{\circ}$ & $-0.16^{\circ}$ & $-0.17^{\circ}$ & $-0.23^{\circ}$ \\
\hline Body surface area & $-0.17^{\circ}$ & -0.09 & -0.11 & -0.18 \\
\hline $\begin{array}{l}\text { Mass of subcutaneous adipose } \\
\text { tissue }\end{array}$ & $-0.30^{\circ}$ & $-0.18^{\circ}$ & $-0.24^{\circ}$ & $-0.30^{\circ}$ \\
\hline $\begin{array}{l}\text { Relative mass of subcut. adipose } \\
\text { tissue }(\%)\end{array}$ & $-0.17^{\circ}$ & -0.09 & -0.11 & -0.18 \\
\hline Relat. mass of fat by Siri (\%) & $-0.31^{\circ}$ & $-0.18^{\circ}$ & $-0.23^{\circ}$ & $-0.32^{\circ}$ \\
\hline Body density $\left(\mathrm{g} / \mathrm{cm}^{3}\right)$ & $0.22^{\circ}$ & 0.08 & $0.17^{\circ}$ & 0.23 \\
\hline $\begin{array}{l}\text { Total cross-sectional area of arm } \\
\left(\mathrm{cm}^{2}\right)\end{array}$ & $-0.23^{\circ}$ & -0.13 & $-0.21^{\circ}$ & $-0.21^{\circ}$ \\
\hline $\begin{array}{l}\text { Total cross-sectional area of thigh } \\
\left(\mathrm{cm}^{3}\right)\end{array}$ & $-0.25^{\circ}$ & $-0.17^{\circ}$ & $-0.21^{\circ}$ & $-0.23^{\circ}$ \\
\hline $\begin{array}{l}\text { Bone-muscle rate of the cross- } \\
\text { sectional area of arm }\left(\mathrm{cm}^{2}\right)\end{array}$ & -0.18 & -0.09 & $-0.19^{\circ}$ & -0.15 \\
\hline $\begin{array}{l}\text { Fat rate of the cross-sectional area } \\
\text { of } \operatorname{arm}\left(\mathrm{cm}^{2}\right)\end{array}$ & $-0.22^{\circ}$ & -0.13 & $-0.18^{\circ}$ & $-0.21^{\circ}$ \\
\hline $\begin{array}{l}\text { Fat rate of the cross-sectional area } \\
\text { of thigh }\left(\mathrm{cm}^{2}\right)\end{array}$ & $-0.27^{\circ}$ & -0.16 & $-0.22^{\circ}$ & $-0.27^{\circ}$ \\
\hline
\end{tabular}

\begin{tabular}{|l|l|l|l|l||}
\hline \multicolumn{2}{|l|}{ Weight classes } & Light & Medium & Heavy \\
\hline \multirow{3}{*}{$\begin{array}{l}\text { Height } \\
\text { classes }\end{array}$} & Short & Small & & \multicolumn{2}{|c|}{ Pycno- } \\
\cline { 2 - 4 } & Medium & Lepto- & Medium & morphic \\
\cline { 2 - 5 } & Tall & Larphic & & Large \\
\hline
\end{tabular}

Figure 1. Body build classes 
Thus, the five height-weight SD classes were created according to the following rules:

Class 1 (small):

weight $<\overline{\mathrm{X}}_{\mathrm{w}}-0.5 \mathrm{SD}_{\mathrm{w}}$ and height $<\overline{\mathrm{X}}-0.5 \mathrm{SD}_{\mathrm{h}}$

Class 2 (medium):

$\overline{\mathrm{x}}_{\mathrm{w}}-0.5 \mathrm{SD}_{\mathrm{w}} \leq$ weight $<\overline{\mathrm{x}}+0.5 \mathrm{SD}_{\mathrm{w}}$ and $\overline{\mathrm{x}}_{\mathrm{h}}-0.5 \mathrm{SD}_{\mathrm{h}} \leq$ height $<0.5 \mathrm{SD}_{\mathrm{h}}$

Class 3 (large):

weight $\geq \overline{\mathrm{x}}_{\mathrm{w}}+0.5 \mathrm{SD}_{\mathrm{w}}$ and height $\geq \overline{\mathrm{x}}_{\mathrm{h}}+0.5 \mathrm{SD}_{\mathrm{h}}$

Class 4 (pycnomorphs):

weight $\geq \bar{x}_{\mathrm{w}}-0.5 \mathrm{SD}$ and height $<\overline{\mathrm{x}}_{\mathrm{h}}-0.5 \mathrm{SD}_{\mathrm{h}}$ or

weight $\geq \overline{\mathrm{x}}_{\mathrm{w}}+0.5 \mathrm{SD}$ and height $<\overline{\mathrm{x}}+0.5 \mathrm{SD}_{\mathrm{h}}$

Class 5 (leptomorphs):

weight $<\overline{\mathrm{X}}_{\mathrm{w}}-0.5 \mathrm{SD}$ and height $\geq \overline{\mathrm{x}}_{\mathrm{h}}-0.5 \mathrm{SD}_{\mathrm{h}}$ or

weight $<\overline{\mathrm{X}}_{\mathrm{w}}+0.5 \mathrm{SD}$ and height $\geq \overline{\mathrm{x}}_{\mathrm{h}}+0.5 \mathrm{SD}_{\mathrm{h}}$ (see Fig. 1 ).

The subjects were placed into the classes of this classification according to their individual heights and weights (Table 2). Thereafter, the mean values of all the 29 anthropometric variables were calculated for all classes. Then the mean values of energy, proteins, fats and carbohydrates in the food consumed were added.

Using the Scheffé-test, the class means of all anthropometric and nutrient data were compared between classes 1-3 but also between classes 4 and 5 , using the significance level $\mathrm{a}=0.05$.

Statistical analysis was performed by one of the authors of the article, namely Säde Koskel MSc. 


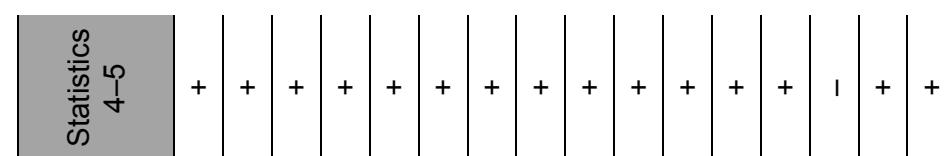

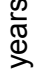

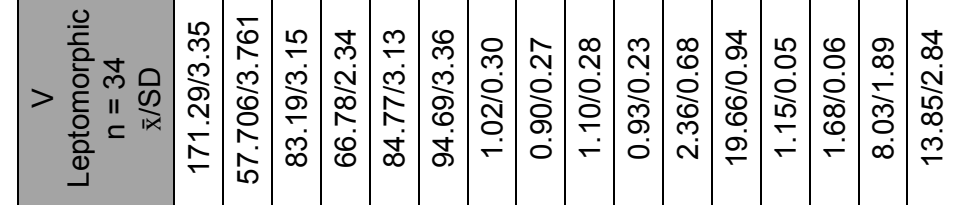

疋

$\frac{\infty}{\frac{1}{0}}$

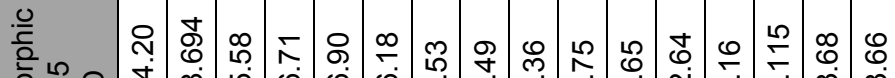

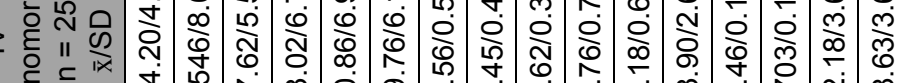

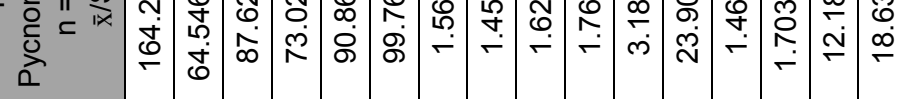

$\frac{\Phi}{\mathscr{E}}$

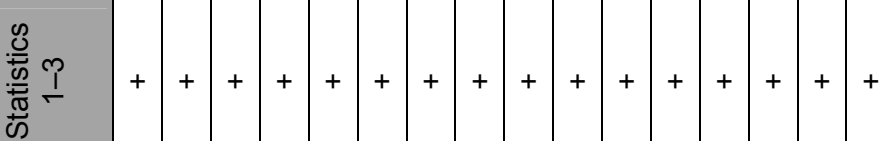

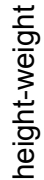

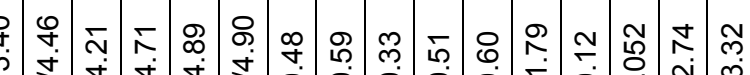

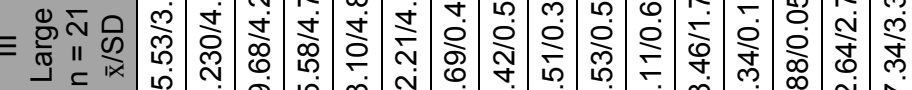
定

毫

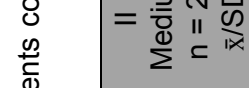

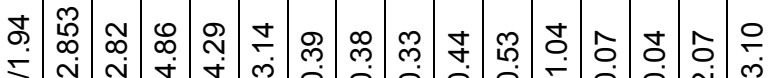

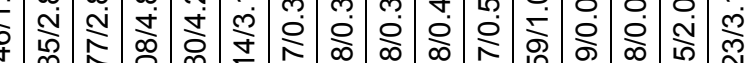

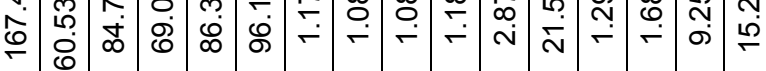

产

若

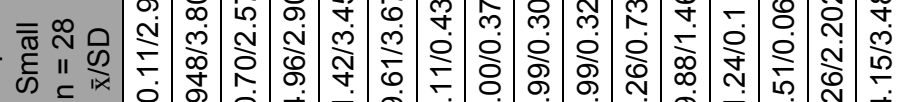

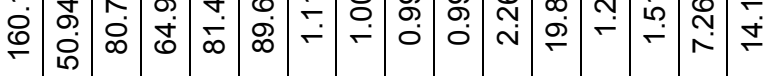

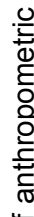

¿

$\frac{\sqrt{2}}{\frac{3}{2}}$

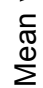

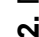

हี

हृ

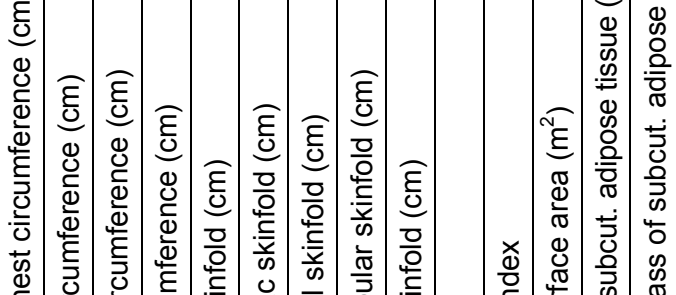

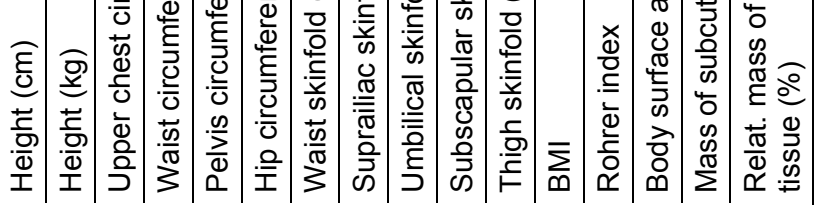




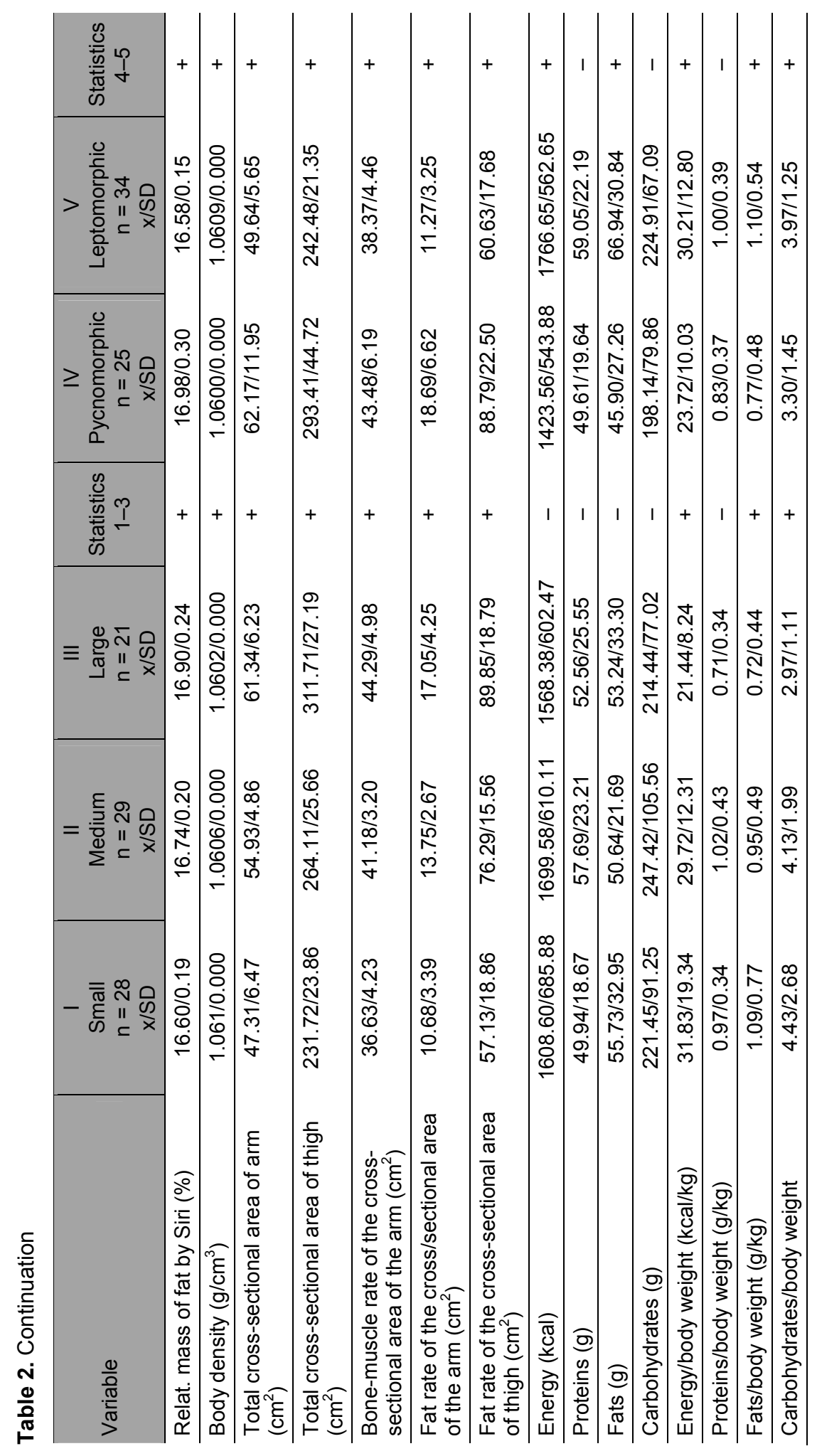




\section{RESULTS}

The study of relations between body build and nutrition started from correlation analysis. Table 1 presents the correlation coefficients of all the 29 anthropometric variables that showed significant correlation with nutrition. It may be surprising that the impact of body composition is clearly revealed in the amount of food consumed. While body fat indicators are in negative correlation with the amount of food consumed, body density was the only indicator that showed positive correlations. The strongest correlations could be found between body measurements and carbohydrates content in food; the strength of these correlations reaches $r=0.32$. In addition to clearly discernible differences in body composition, the essence of body build as a whole could also be noticed. We are used to thinking that the main indicator is body weight. Correlation analysis, however, shows that thicknesses of individual skinfolds are no less important for representing the body as a whole. Thus, the correlation between body weight and the amount of food energy consumed is $\mathrm{r}=-0.21$, but suprailiac skinfold $(\mathrm{r}=-0.28)$ and umbilical skinfold $(\mathrm{r}=-0.30)$ demonstrate even stronger correlations. The peculiarities of body composition are similarly represented by BMI, Rohrer index and total cross-sectional areas of the arm and the thigh. Body height alone does not correlate with the amount of food consumed, but it is the most significant component representing body size, shape and density.

Consequently, the anthropometric model for nutrition research might be a classification that would facilitate the systematisation of body size, shape and composition within the population under study. In our research, we applied a 5 SD classification of height and weight.

In Table 2, all the young women $(\mathrm{n}=131)$ were placed into classes according to their individual heights and weights. For all the classes, the mean values of the 29 body measurements and body composition characteristics, food energy and the main nutrients consumed were calculated, and the significance of differences was assessed by the t-test.

The table shows that the gradual increase in height and weight in classes small-medium-big brings about a gradual, statistically significant increase in all the circumferences, skinfolds, BMI, Rohrer index, indicators of subcutaneous adipose tissue and total fat content, body density, total cross-sectional areas of the arm and the thigh, fat rates in the arm and the thigh, and bone-muscle rate in the arm. 
The same variables also differ clearly in the classes of pyknomorphs and leptomorphs. In the class of pyknomorphs, body fat content is significantly higher and body density significantly lower than in the class of leptomorphs.

As food energy and main nutrients consumption, no statistically significant differences were revealed between the first three classes.

Interesting differences, however, appeared in calculations per $1 \mathrm{~kg}$ of body weight. The amount of energy as well as carbohydrates and fats consumed per $1 \mathrm{~kg}$ of body weight decreases gradually in the direction from small to medium to large. Protein consumption also shows a similar decreasing trend, but the differences between the classes are not significant.

The consumption of energy and main nutrients in the class of pyknomorphous young women was lower than in the class of leptomorphs in total amount as well as per $1 \mathrm{~kg}$ of body weight. The same cannot be statistically proved about the total amount of proteins and carbohydrates consumed and their consumption per $1 \mathrm{~kg}$ of body weight, although a corresponding tendency exists.

\section{DISCUSSION}

The results of our study indicated that the peculiarities of body build - height, weight, body composition - have significant correlations with the amount of food energy and main nutrients consumed. The problem, however, consists in finding an anthropometric classification that could serve as a basis for statistical analysis of a great number of body build and nutritional data.

Our results suggest that this could be a 5 SD classification of height and weight. Our long-term studies on the whole body anthropometric structure have confirmed that the body as an anthropometric whole consists of individual characteristics that show statistically significant mutual correlations, where the leading characteristics are height and weight. Height and weight correlate most closely with all other characteristics and determine more than $50 \%$ of the variability of all the individual characteristics $[4,5]$.

While creating the classification, we took into consideration that it could be used to characterise different stages of concordance between height and weight (small, medium, large) [6] and simultaneously characterise the classical somatotypes - pyknics and leptosomes [8] as the greatest manifestations of disconcordance between height and weight.

Our detailed comparative studies on the body structure of pyknics, leptosomes and other body build classes have shown that the bodies of pyknics and 
leptosomes have no special structure but are also based on relations between height and weight [3].

As body fat content and body density are two very essential factors from the viewpoint of nutrition, the classes of pyknomorphs and leptomorphs in the current classification present a splendid opportunity to compare the nutritional data of persons belonging to these classes [13].

Our experience in studying the body structure of many different populations (schoolchildren, young women, conscripts) has shown that in such a classification many length, breadth and depth measurements, circumferences and body composition characteristics fall into a system according to classes [4, $9,12,15]$. One of the advantages of this classification is that it consists of SD classes; therefore, the mean anthropometric data of populations of different ages or nationalities, when analysed in an analogous way, are mutually comparable.

It should be noted that the significance of only one indicator - body mass index - in nutrition studies should not be overestimated. Although this index has been formed from height and weight, it characterises only obesity and, therefore, it cannot replace the analysis of different body types. For example, in our study, the BMI of small and leptosomic classes was almost equal, although these body types are greatly different.

\section{REFERENCES}

1. Buddeberg-Fischer B., Bernet R., Sieber M., Buddeberg C. (1996). Epidemiology of eating behaviour and weight distribution in 14- to 19-year-old Swiss students. Acta Psychiatr. Scand. 94, 296-304.

2. Kaarma H. (1981). Multivariate statistical analysis of women's anthropometric characteristics system. Tallinn: Valgus.

3. Kaarma H. (1995). Complex statistical characterization of women's body measurements. Anthrop. Anz. 53, 239-244.

4. Kaarma H., Stamm R., Kasmel J., Koskel S. (2005). Body build classification for ordinary schoolgirls (aged 7-18 years) and volleyball girls (aged 13-16 years). Anthrop. Anz. 63, 77-92.

5. Kaarma H., Veldre G., Stamm R., Lintsi M., Kasmel J., Maiste E., Koskel S. (2001). Regularities of body build structure of Estonian girls and youths. Morphology 120, 80-82 (in Russian).

6. Knußmann R. (1961). Makrosomie-Mikrosomie als körperbautypologische Variationsreihe II. Ordnung. - Homo, 12, 1-16. 
7. Knußmann R. (1988). Anthropologie. Handbuch der vergleichenden Biologie des Menschen. Band I: Wesen und Methoden der Anthropologie. Gustav-FischerVerlag. Stuttgart/New York.

8. Kretschmer E. (1961). Körperbau und Charakter. Berlin/Göttingen/Heidelberg: Springer Verlag. (1. Aufl. 1921).

9. Lintsi M., Kaarma H., Saluste L., Vasar V. (2002). Systemic changes in body structure of 17-18-year-old schoolboys. Homo 53, 157-169.

10. Loolaid K., Loolaid V., Kaarma H., Saluste L. (1999). Dietary intake and body structure of girls from secondary schools of Tartu. Papers on Anthropology VIII, 103-107.

11. Micro-Nutrica, Food and Nutrition (1997). Tallinn Technical University, Department of Food Processing.

12. Peterson J., Saluvere K. (1998). Systematisation of anthropometric data of 18-year-old girls by statistical model. Biol. Sport 15, 105-112.

13. Peterson J., Kaarma H., Koskel S. (2007). Using a height-weight classification for analysis of food energy and main nutrient content in 24-hours menus of 17-23year-old Estonian female students. Anthrop. Anz. 65, 1, 51-59.

14. Rolland-Cachera M. F., Bellisle F., Deheeger M. (2000). Nutritional status and food intake in adolescents living in Western Europe. Eur. J. Clin. Nutr. 54, 41-46.

15. Saluvere K., Peterson J., Saluste L., Koskel S. (1998). Systematisation of anthropometric data of 17-year-old schoolgirls from Tartu, Estonia. Anthrop. Anz. 56, 267280.

16. Wardle J., Steptoe A., Bellisle F., Davou B., Reschke K., Lappalainen R., Fredrikson M. (1997). Healthy dietary practices among European students. Health Physiol. 16, 443-450.

17. Wilmore J. H., Behnke A. R. (1970). An anthropometric estimation of body density and lean body weight in young women. Amer. J. Clin. Nutr. 23, 267-274.

\section{Address for correspondence:}

Helje Kaarma Dr.Sc., Dr.med.

Centre for Physical Anthropology

Institute of Anatomy

Faculty of Medicine

University of Tartu

E-mail: antrop@ut.ee 